\title{
Ensuring energy security in the context of the implementation of import substitution and innovative development policies
}

\author{
Arthur Gibadullin,", Valery Abramov ${ }^{2}$, Tufa Usmanova $^{3}$, Svetlana Bryukhovetskaya ${ }^{2}$, \\ Andrei Borisov, and Olga Afanasieva ${ }^{4}$ \\ ${ }^{1}$ State University of Management, 99, Ryazan Avenue, Moscow, 109542, Russian Federation \\ ${ }^{2}$ Financial University under the Government of the Russian Federation, 49, Leningradsky avenue, \\ Moscow, 125993, Russian Federation \\ ${ }^{3}$ The Technological University of Tajikistan, 63/3, N. Karaboev, Dushanbe, 734055, The Republic of \\ Tajikistan \\ ${ }^{4}$ Russian University of Transport, 9b9, Obrazcova Street, Moscow, 127994, Russian Federation
}

\begin{abstract}
The study is aimed at studying energy security in the electricity sector and developing measures aimed at increasing the share of domestic innovative equipment. The paper analyzes indicators related to the amount of installed capacity, the output and commissioning of power equipment and the share of foreign equipment used. As a result of the analysis, an increase in equipment depreciation, a drop in the indicators of qualitative renewal of fixed assets, and a high share of foreign-made equipment were revealed. At the end of the study, measures were proposed that allow for a better policy in the field of import substitution and innovative development of the electric power complex.
\end{abstract}

\section{Introduction}

In recent decades, issues related to maintaining the autonomy of states, as well as independence from external interference in the functioning and development of basic business processes have come to the fore. Strengthening the processes associated with the need to ensure the safety of all spheres of human life, and the Russian economy, were updated in 2014, when sanctions were introduced against Russia, which required a revision of the state's position on a number of issues. Today, the issues of ensuring the security of various fields of activity are the main priority for the Russian economy, however, in our study we decided to consider energy security, since it is electricity that is the basic industry and ensures the functioning of all types of economic activity [1-2].

The basis of energy production in Russia was formed back in the Soviet period, when the basic production units were created, new types of activities were created, and the Unified Energy System was formed, containing the technological chain of production transmission - distribution - sale consumption of electric energy. The potential formed during the Soviet period is already morally and physically obsolete, which requires the

* Corresponding author: 11117899@mail.ru 
electric power industry to search for new, cost-effective and environmentally friendly technologies [3-5].

To date, the electric power complex uses either outdated equipment or equipment of foreign production, primarily because the Russian economy does not provide energy production with the necessary equipment [6-8]. Of course, these problems are caused by the lack of personnel in the economy, scientific and technical potential, technological reserves, production capacities, material and labor resources. Such a situation may adversely affect the energy security of Russia, in this regard, it is advisable to develop these areas in order to systematically switch to domestic technologies.

\section{Materials and methods}

The purpose of the study is to develop mechanisms to ensure the energy security of Russia. Based on the goal, the following tasks were formed:

- analyze the level of energy security of the Russian electric power industry;

- form measures to ensure the energy security of the electric power industry.

The study used open data from the Russian Ministry of Energy and the Federal State Statistics Service. To conduct an objective analysis, various scientific methods were used, which made it possible to reveal the goal of the study.

\section{Results}

Energy security in the modern world is an essential element for ensuring the socioeconomic stability of regions and maintaining the welfare of the population. Energy security is a set of measures aimed at ensuring reliable, uninterrupted and efficient functioning of electric power facilities that provide energy to various groups of consumers. Of course, the current situation in the Russian economy and its foreign economic activity requires a close study and development of measures to ensure the energy security of the electric power complex.

Ensuring energy security should be carried out in three main areas - this is updating production capacities, reducing the share of imported equipment in the production process and increasing the level of innovative and technological development of fixed assets. Research [9-12], devoted to issues of assessing the level of physical and moral depreciation of fixed assets, indicates that about $50 \%$ of all capacities are worn out, the share of equipment operated outside the park resource is increasing every year, and the level of innovative products does not exceed $5-8 \%$.

Of course, in order to ensure the effective functioning of electric power facilities and ensure energy security, it is advisable to update production capacities, in this regard, we will analyze the installed capacity at the beginning and end of 2018, we will estimate the share of installed and withdrawn installed capacities during the year (figure 1) [13-14].

It can be seen from the figure that in a number of combined power systems the volumes of installed capacities increase, but in some, such as the UES of the Center and the UES of Siberia, the installed capacity decreases. At the same time, in 2018, $1950 \mathrm{MW}$ of installed capacity was withdrawn, and 4792 MW commissioned, which does not mean a $100 \%$ upgrade of production capacities, but rather an increase in production capacities to provide energy to new consumers [15].

Thus, as of January 1, 2018, the installed capacity of UES of Russia amounted to $239812 \mathrm{MW}$, and as of December 31, 2018 their volume increased by $3431 \mathrm{MW}$. 


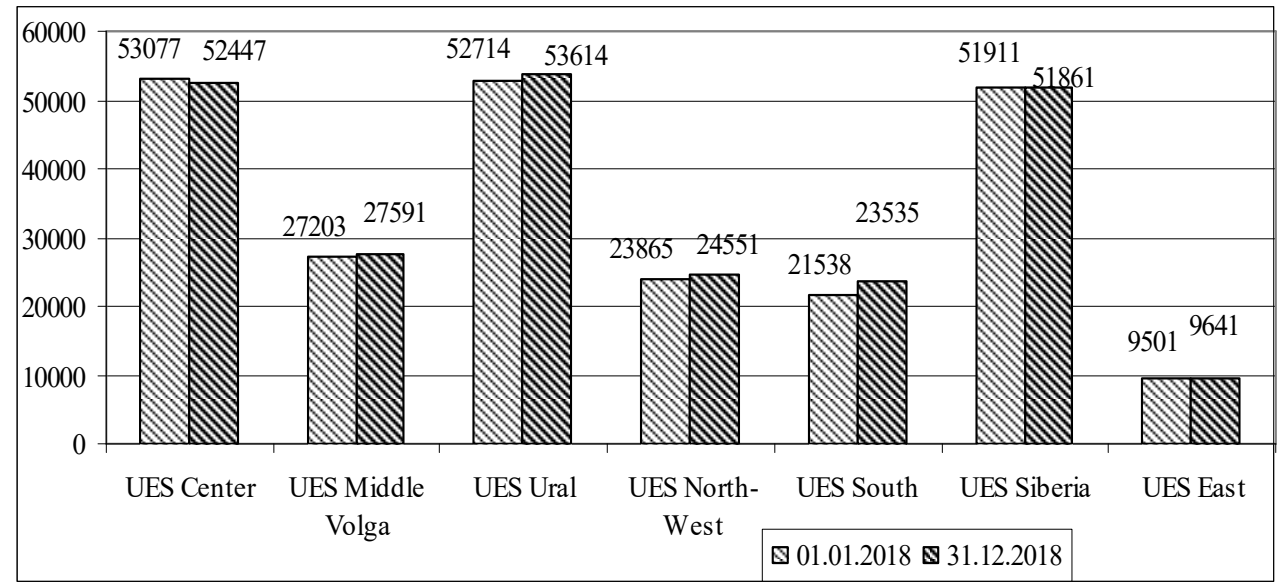

Fig 1. Installed capacity of the integrated energy systems of Russia, MW.

Next, we present the share of foreign-made equipment operated at electric power facilities (figure 2) [13-14].

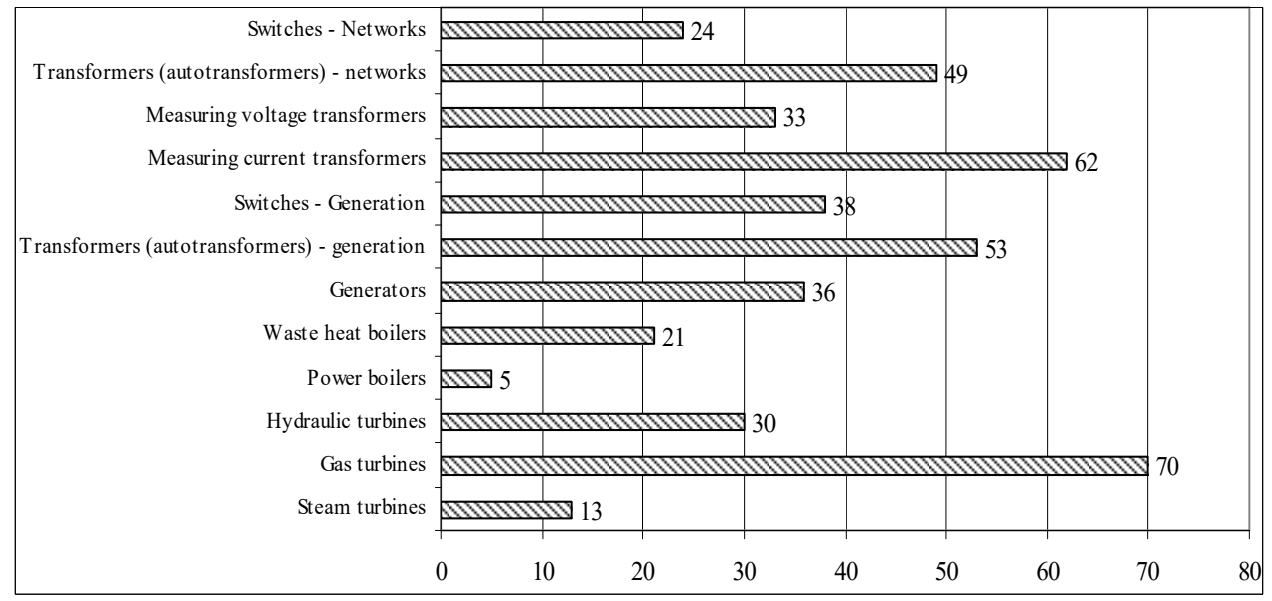

Fig. 2. Percentage of the main equipment of foreign production operated at electric power facilities, of the total, in percent.

The figure shows that for individual power equipment, the share of foreign equipment is minimal, since equipment operates outside the park resource, which was commissioned back in the 50-60s of the last century. At the same time, more modern equipment, such as autotransformers, transformers and gas turbines, are foreign production.

Consider the indicators of the technical condition of the main equipment (table) [13-14].

It can be seen from the table that the service life of the main equipment of generating and network companies is 27 and 22 years, respectively, while the most recent is foreign equipment, and the oldest is Russian-made. The share of the main equipment operated outside the park resource, foreign production is $10 \%$, and Russian - $60 \%$, a similar situation is observed in terms of the average number of spent park resources.

Thus, it can be seen from the analysis that not only the share of foreign equipment used in Russian energy production is high, but also the volume of equipment used outside the park resource, which, of course, reduces the energy security of the Russian electric power complex. In this regard, it is necessary to envisage measures aimed at the development of 
domestic power engineering and increasing the share of innovative equipment at electric power enterprises [16-17].

Table 1. The main indicators of the technical condition of the main equipment of foreign production

\begin{tabular}{|c|c|c|c|c|}
\hline Indicator & Total & $\begin{array}{c}\text { Foreign } \\
\text { production }\end{array}$ & $\begin{array}{c}\text { Ukrainian } \\
\text { production }\end{array}$ & $\begin{array}{c}\text { Russian } \\
\text { production }\end{array}$ \\
\hline \multicolumn{5}{|c|}{ Average service life of equipment, years } \\
\hline Generation companies & 27 & 9 & 24 & 33 \\
\hline Electricity companies & 22 & 7 & 27 & 25 \\
\hline The share of the main equipment operated outside the park resource / service life, \\
as a percentage \\
\hline Generation companies & 50 & 10 & 40 & 60 \\
\hline Electricity companies & 50 & 10 & 70 & 60 \\
\hline \multicolumn{6}{|c|}{ Average amount of spent park resources / service life } \\
\hline Generation companies & 0.93 & 0.34 & 0.95 & 1.12 \\
\hline Electricity companies & 0.97 & 0.28 & 0.28 & 1.105 \\
\hline
\end{tabular}

\section{Discussions}

Such dependence of the Russian energy sector on significant images affects the energy security of Russia. According to the draft Energy Strategy of Russia until 2035 [18], the main tasks in the field of import substitution should be based on the following [18]:

- development and optimization of various forms of public-private partnership in order to improve the quality of the equipment manufactured;

- creation of our own scientific, technical, innovative and industrial potential for the implementation of a qualitative transition to new technologies in the electric power industry.

In addition, the strategy states that for the implementation of these tasks it is necessary to be based on the development and adoption of the following measures [18]:

- tax and customs incentives for the development and use of Russian equipment and its components;

- issuance of soft loans, loans and other subsidies that contribute to the creation of new Russian equipment;

- creating conditions for the creation of engineering and scientific centers;

- localization of production of available technologies;

- creation of associations of scientific, educational and industrial potential in order to create new equipment and technologies;

- creation of test sites on the basis of corporate, state, private and scientific and educational organizations.

In the opinion of the authors of the study, it is necessary to develop additional measures that contribute to the development of appropriate technologies for domestic production. Among them, it is advisable to highlight the following activities [19-23]:

- formation of a favorable investment environment for the Russian economy;

- the creation of new power engineering industries, allowing to reunite the necessary scientific and technical potential;

- the formation and development of cluster formations, in which all the necessary labor, material and technical resources will be concentrated in order to ensure innovative and technological development of the electric power industry;

- creation of a supranational platform for the exchange of information and technological solutions that affect the development of innovative potential. 
Thus, in order to ensure import substitution and innovative development, it is necessary to make decisions at the state level that will contribute to a qualitative and quantitative change in the energy industry, as well as preserve Russia's energy security.

\section{Conclusion}

The study made it possible to analyze the energy security of the electric power complex, in the framework of which there were revealed drops in the level of qualitative renewal of fixed production assets, high shares of the use of foreign equipment and technologically backward equipment. In order to ensure energy security, the main recommendations were formed that are based on various mechanisms to ensure a high-quality transition to innovative technologies of the Russian electric power complex.

\section{References}

1. Z.K. Omarova, S. Ivanovichnikishov, A.S. Ellaryan, A.D. Bobryshev, E.Y. Kamchatova, Journal of Advanced Research in Dynamical and Control Systems, 10, S10, 581-586 (2019) DOI: 10.5373/JARDCS/V11SP10/20192845

2. E.V. Kulyasova, N.S. Kulyasov, A.Yu. Puchkov, Journal of Physics: Conference Series, 1260, 032024 (2019) DOI: 10.1088/1742-6596/1260/3/032024

3. D.E. Morkovkin, Sententia. European Journal of Humanities and Social Sciences, 1, 41-47 (2019) DOI: 10.25136/1339-3057.2019.1.26990

4. I.A. Ivanova, V.N. Pulyaeva, L.V. Vlasenko, A.A. Gibadullin, M.I. Sadriddinov, Journal of Physics: Conference Series, 1399, 033038 (2019) DOI:10.1088/1742$6596 / 1399 / 3 / 033038$

5. V.N. Zakharov, V.Y. Linnik, Y.N. Linnik, A.B. Zhabin, Mining Informational and Analytical Bulletin, 5, 5-12 (2019) DOI: 10.25018/0236-1493-2019-05-0-5-12

6. Y.N. Linnik, V.Y. Linnik, A.B. Zhabin, A.V. Polyakov, Mining Informational and Analytical Bulletin, 8, 33-41 (2019) DOI: 10.25018/0236-1493-2019-08-0-33-41

7. S.V. Bryukhovetskaya, K.A. Artamonova, A.A. Gibadullin, S.A. Ilminskaya, Z.M. Kurbonova, IOP Conference Series: Earth and Environmental Science, 421, 042018 (2020) DOI: 10.1088/1755-1315/421/3/042018

8. V.N. Zakharov, V.Y. Linnik, Y.N. Linnik, E.A. Averin, Eurasian Mining, 1, 40-42 (2019) DOI: 10.17580/em.2019.01.10

9. D.S. Lopatkin, T.N. Shushunova, G.E. Shaldina, A.A. Gibadullin, I.L.Smirnova, Journal of Physics: Conference Series, 1399, 033061 (2019), DOI:10.1088/17426596/1399/3/033061

10. D.I. Zimnukhova, G.A. Zubkova, D.E. Morkovkin, P.V. Stroev, A.A. Gibadullin, Journal of Physics: Conference Series, 1399, 033097 (2019), DOI:10.1088/17426596/1399/3/033097

11. A. Sozontov, M. Ivanova, A. Gibadullin, E3S Web of Conferences, 114, 01009 (2019) https://doi.org/10.1051/e3sconf/201911402002

12. D.E. Morkovkin, Ch.V. Kerimova, O.I. Dontsova, A.A. Gibadullin, Journal of Physics: Conference Series, 1399, 033042 (2019) DOI:10.1088/17426596/1399/3/033042

13. Russian statistical yearbook 2018 (Moscow: Rosstat) 694

14. Website of the Ministry of Energy of the Russian Federation, www.minenergo.gov.ru 
15. V.V. Davnis, V.I. Tinyakova, V.A. Fetisov, M.A. Chervontseva, S.I. Oparina, International Journal of Recent Technology and Engineering, 8, 3, 254-260 (2019) DOI: 10.35940/ijrte.C1059.1083S19

16. G.V. Butkovskaya, E.V. Sumarokova, E-management, 2, 3, $48-57$ (2019) DOI: 10.26425/2658-3445-2019-3-48-57

17. S. Miloslavskaya, A. Panychev, A. Myskina, P. Kurenkov, E. Rudakova, IOP Conference Series: Materials Science and Engineering, 698(6), 066065 (2019) DOI: 10.1088/1757-899X/698/6/066065

18. The website of the energy strategy of Russia until 2035, www.minenergo.gov.ru/node/1920

19. I.A. Ivanova, V.N. Pulyaeva, L.V. Vlasenko, A.A. Gibadullin, B.G. Safarov, IOP Conference Series: Earth and Environmental Science, 421, 032039 (2020) DOI: 10.1088/1755-1315/421/3/032039

20. S.A. Tolkachev, A.A. Bykov, D.E. Morkovkin, O.I. Borisov, A.V. Gavrilin, IOP Conference Series: Earth and Environmental Science, 421, 032041 (2020) DOI: 10.1088/1755-1315/421/3/032041

21. E.V. Ganina, N.M. Malyugina, R.I. Polyakova, E.A. Fedorova, O.N. Bykova, International Journal of Engineering and Advanced Technology, 9(1), 5565-5569 (2019) DOI: 10.35940/ijeat.A2128.109119

22. J.V. Gnezdova, E.N. Rudakova, O.P. Zvyagintseva, Studies in Systems, Decision and Control, 169, 211-218 (2019) DOI: 10.1007/978-3-319-94310-7_21

23. Z. Wang, V.V. Utemov, E.G. Krivonozhkina, G. Liu, A.A. Galushkin, Eurasia Journal of Mathematics, Science and Technology Education, 14(1), 543-552 (2018) DOI: 10.12973/ejmste/80613 